\title{
Subject Visit End Date Time
}

National Cancer Institute

\section{Source}

National Cancer Institute. Subject Visit End Date Time. NCI Thesaurus. Code C83435.

The date and time a subject visit has concluded. 